\title{
MAXWELL'S DEMON WENT DOWN TO GEORGIA
}

\section{It's the thought that counts.}

\section{BY MARISSA LINGEN}

$\mathrm{I}$

$\mathrm{t}$ was a few minutes to midnight at a crossroads in Georgia. Johnny had his fiddle in his hand. He knew what to expect. The seconds ticked by, and Johnny counted them anxiously.

The horned, red, cloven-hoofed creature showed up right on time. The infernal host are nothing if not punctual.

"All right, Satan," said Johnny. "I know how this works. I bet my eternal soul against you in a fiddle-playing contest, and you bet a golden fiddle. Are you ready?"

The scarlet countenance looked at him reproachfully. "You've got me wrong. I'm not Satan. I'm Maxwell's Demon."

Johnny was a musician. "Who?" he said.

"Very famous thought experiment. I only let the faster-than-average electrons through the gate. It's a thermodynamics thing."

"Have you got a silver hammer?"

"No."

"Never heard of you. What are you doing at a crossroads in Georgia anyway?"

"I believe there was something about a rambling wreck?” Maxwell's Demon ventured. "And I took a wrong turn on Piedmont Avenue." Johnny folded his arms, letting his fiddle hang loose, and glared at the creature. "Look, but I don't play the fiddle," Maxwell's Demon continued.

Johnny grinned. "Even better."

"Can you see how I am not likely to get into a contest - for souls or any other prize — involving an instrument I don't even play? It's ridiculous!"

Johnny thought about it. "Do you play any instruments?"

"I have been known to dabble in the theremin," the demon admitted.

"What's that?"

The demon made enthusiastic circling, pinching gestures. "It's the one that goes woooeeeeeeeoooooo, sort of hauntedhouse-y noises."

"Oh." Johnny thought about it. He had been a musician for long enough to be con-

$\rightarrow$ NATURE.COM

Follow Futures:

@ @NatureFutures

$f$ go.nature.com/mtoodm fident in his ability to get a pleasant noise out of just about anything. "All right, I'll give that a go."

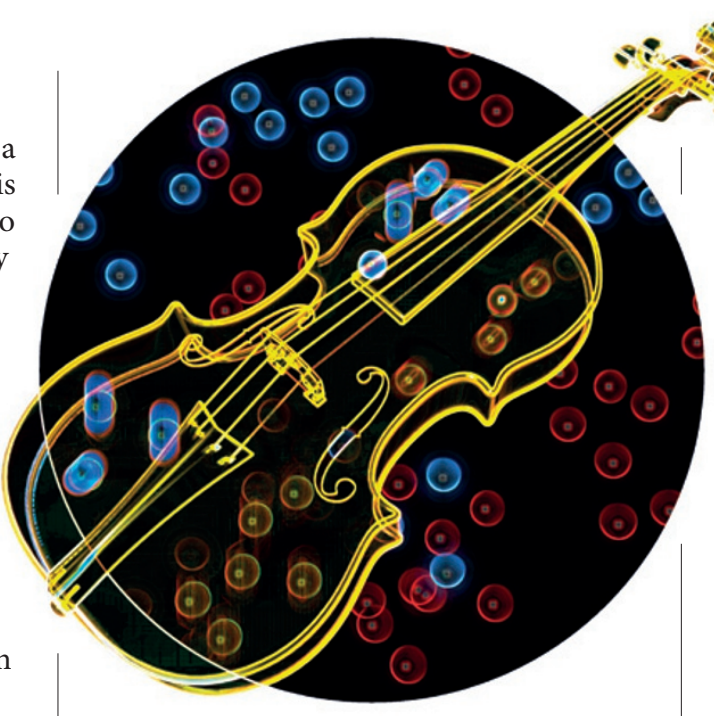

"I don't have a golden fiddle to bet you, and I don't want your immortal soul," said Maxwell's Demon.

Johnny waved his hand. "Equivalent values?" "All right."

"But you have to go first, as I've never played one of these."

"All right," the demon repeated. He conjured a theremin into the dark air of the crossroads. Johnny peered at it as the demon poised his long, tapered red fingers and then began.

The sounds that filled the air would have seemed eerie and strange if Johnny had not been so focused on how the demon was producing them. They had a round and sliding quality, slipping from one tone to another; after a moment Johnny realized that he associated them not only with haunted houses, but also with Doctor Who.

Maxwell's Demon played a sweet melody that ranged from playful to sad, major to minor and back again. It took several moments to die away when his hands stopped dancing over the theremin.

"All right?" he said to Johnny.

"I think so."

"Then take your turn." The demon gestured, and the strange little box disappeared from in front of the demon and appeared in front of Johnny.

Johnny gestured, and the theremin farted. He flushed. "That doesn't count."

"When you're ready," the demon agreed.

Johnny pinched a few squeaks out of the theremin. "I'm warming up."
"Every musician needs to warm up and tune their instrument," said the demon. After a few more tentative gestures, Johnny took a deep breath and began to move his hands more like the demon had. He danced them through the range of the theremin, commanding runs and notes, chords and changes.

What he got was even a song. As a beginner's song went, it was pretty good. If he'd been able to start on his fiddle with a song that good, he'd have been thrilled.

But it was not the virtuoso song of Maxwell's Demon.

"Who judges these things anyway?" said Johnny. "I mean, who says mine was best or yours was?"

"I have always wondered," said Maxwell's Demon.

But Johnny knew he had lost. And the demon knew it too.

"All right," Johnny said. "My soul, we said. Equivalent value. What's equivalent value to my soul?"

"What I would really like," said Maxwell's Demon dreamily, "is to arrange your electrons so that the ones on the right are slightly more energetic than the ones on the left. Do you think we could do that? It would feel more ... orderly. That sort of thing makes me very happy."

"Uh, sure," said Johnny. "Not my soul?"

"This is better than souls."

"Knock yourself out." He thought about it. "Wait, can we do it the other way? I bow with my right hand and finger with my left."

"Does that matter?" asked the demon.

Johnny thought wistfully of the golden fiddle he had hoped to have at the end of the evening. Maybe this would be almost as good. "It does to me."

"I can't really tell the difference between left and right," said the demon. "It's probably what got me here instead of Georgia Tech. So when we're done arranging your electrons...?"

"Sure, sure," said Johnny. "I'll help you get there." Maybe they threw money to street musicians at Georgia Tech. It couldn't be worse than what they gave to theremin players at crossroads in rural Georgia, he bet.

Marissa Lingen has published more than 90 short stories in venues such as Analog, Lightspeed and Tor.com. 